\title{
Assessment of atmospheric trace metals in the western Bushveld Igneous Complex, South Africa
}

\section{AUTHORS:}

Pieter G. van Zyl ${ }^{1}$

Johan P. Beukes ${ }^{1}$

Grizelda du Toit ${ }^{1}$

Desmond Mabaso 2,3

Johan Hendriks ${ }^{1}$

Ville Vakkari ${ }^{4}$

Petri Tiitta ${ }^{5}$

Jacobus J. Pienaar ${ }^{1}$

Markku Kulmala ${ }^{6}$

Lauri Laakso $0^{1,4}$

\section{AFFILIATIONS:}

'Unit for Environmental Sciences and Management, North-West University, Potchefstroom,

South Africa

${ }^{2}$ Rustenburg Local Municipality, Rustenburg, South Africa

${ }^{3}$ South African Weather Service, Pretoria, South Africa

${ }^{4}$ Finnish Meteorological Institute, Helsinki, Finland

${ }^{5}$ Department of Environmental Science, University of Eastern

Finland, Kuopio, Finland

${ }^{6}$ Department of Physics, University of Helsinki, Helsinki, Finland

\section{CORRESPONDENCE TO:} Pieter van Zyl

EMAIL:

Pieter.vanzyl@nwu.ac.za

\section{POSTAL ADDRESS:}

Unit for Environmental Sciences and Management, North-West University, Potchefstroom Campus, Private Bag X6001, Potchefstroom 2520, South Africa

\section{DATES:}

Received: 04 Sep. 2013

Revised: 30 0ct. 2013

Accepted: 05 Nov. 2013

\section{KEYWORDS:}

air quality; temporal assessment; principal component factor analysis; source apportionment

\section{HOW TO CITE:}

Van Zyl PG, Beukes JP, Du Toit G, Mabaso D, Hendriks J, Vakkari V, et al. Assessment of atmospheric trace metals in the western Bushveld Igneous Complex, South Africa. S Afr J Sci. 2014;110(3/4), Art. \#2013-0280, 11 pages. http://dx.doi.org/10.1590/ sajs.2014/20130280
Trace metal species emitted into the atmosphere from natural and anthropogenic sources can cause various health-related and environmental problems. Limited data exist for atmospheric trace metal concentrations in South Africa, which has the largest industrialised economy in Africa, with significant mining and metallurgical activities. A large fraction of these mineral assets is concentrated in the Bushveld Igneous Complex, with the western limb being the most exploited. To partially address this knowledge gap, atmospheric trace metals were collected in the western Bushveld Igneous Complex at Marikana in the North West Province. Diurnal $\mathrm{PM}_{2.5}$ and $\mathrm{PM}_{10}$ samples were collected for 1 year. A total of 27 trace metal species were determined. With the exception of $\mathrm{Ni}$, none of the trace metals measured during the sampling period exceeded local or international air quality standard limit values. Total trace metal concentrations in the $\mathrm{PM}_{10}$ fraction peaked during the dry months and were regularly washed out during the wet season. A less significant seasonal trend was observed for the trace metal concentrations in the $\mathrm{PM}_{2.5}$ fraction; a finding attributed to a faster replenishment of smaller particles into the atmosphere after rain events. About $80 \%$ of the $\mathrm{PM}_{10}$ trace metal levels measured occurred in the $\mathrm{PM}_{2.5}$ fraction, while $40 \%$ or more of all metals emanated from the $\mathrm{PM}_{2.5}$ fraction. This finding indicated a strong influence of anthropogenic sources. Four meaningful emission sources were determined from explorative principal component factor analysis: crustal, vanadium related, base metal related and ferrochromium related, which correlated well with the anticipated atmospheric trace metal sources in the region.

\section{Introduction}

The presence of trace metal species in the atmosphere is mainly attributed to the emission of particulate matter (PM) into the atmosphere by anthropogenic activities and natural sources. Gravimetrically, trace metals represent a relatively small proportion of atmospheric aerosols (generally less than 1\%). ${ }^{1}$ Natural emissions of trace metals result from different processes acting on crustal minerals, e.g. erosion, surface winds and volcanic eruptions, as well as from natural burning and from the oceans. Sodium (Na), magnesium ( $\mathrm{Mg}$ ), aluminium (Al), potassium (K), calcium (Ca), titanium (Ti), chromium ( $\mathrm{Cr}$ ), iron ( $\mathrm{Fe}$ ) and manganese $(\mathrm{Mn})$ are usually associated with mineral dust and crustal species. ${ }^{2-5}$ The predominant anthropogenic sources are pyrometallurgy, biomass burning (veld fires), fossil-fuel combustion and incineration. Atmospheric trace metal species usually associated with anthropogenic activities include arsenic (As), cadmium (Cd), copper (Cu), nickel (Ni), zinc (Zn), vanadium (V), mercury (Hg) and lead $(\mathrm{Pb}) .{ }^{6}$ Metal smelting is regarded as one of the most important anthropogenic trace metal emission sources. During smelting processes, metals in the ores are evaporated from the matrix, which could be emitted into the atmosphere if proper pollution control technology is not applied. ${ }^{7}$ Industrial metallurgical processes produce the largest emissions of As, $\mathrm{Cd}, \mathrm{Cu}, \mathrm{Ni}$ and $\mathrm{Zn}{ }^{8}$

Trace metals emitted into the atmosphere can cause a variety of health-related and environmental problems, depending on the extent and time of exposure..$^{9,10}$ The potential hazard of several toxic species such as As, Cd, $\mathrm{Cr}, \mathrm{Hg}$ and $\mathrm{Pb}$ is well documented and guidelines for levels of these species in the atmosphere are provided by the World Health Organization (WHO). ${ }^{11}$ Trace metals such as $\mathrm{Cr}$, Fe and V have several oxidation states and can therefore participate in many important atmospheric redox reactions ${ }^{1}$, which can catalyse the generation of reactive oxygen species that have been associated with direct molecular damage and with the induction of biochemical synthesis pathways ${ }^{12,13}$.

Only a few studies on the concentrations of atmospheric trace metals in South Africa have been conducted. ${ }^{12,14-17}$ South Africa has the largest industrialised economy in Africa, with significant mining and metallurgical activities. A large fraction of the South African mineral assets is concentrated in the Bushveld Igneous Complex (BIC). In Figure 1, the BIC is indicated on a geographical map of South Africa. The BIC covers an area of $66000 \mathrm{~km}^{2}$, which stretches across the North West, Gauteng, Mpumalanga and Limpopo Provinces. ${ }^{18}$ This region holds numerous metallurgical operations as a result of large deposits of $\mathrm{V}, \mathrm{Ni}, \mathrm{Cu}, \mathrm{Cr}$, cobalt (Co) and tin ( $\mathrm{Sn}$ ). As much as $80 \%$ of the world's platinum group metals (PGMs) are also produced from the BIC..$^{19-21}$ Platinum is important in the mitigation of global atmospheric pollutants, because it is mainly used in catalytic converters of vehicular exhaust systems. ${ }^{17}$

The BIC is geographically subdivided into five limbs, of which the western limb is the most exploited and industrially developed. ${ }^{18}$ The western BIC also forms part of an air pollution priority area recently declared by the South African Government - the Waterberg-Bojanala National Air Quality Management Priority Area. ${ }^{22}$ This declaration indicates the relevance and significance of atmospheric pollution in this region. In this study, atmospheric trace metals were collected in the western BIC at Marikana in the North West Province (Figure 1). Marikana is surrounded by more than 30 mines and 11 pyrometallurgical smelters (indicated in Figure 1) within a 60-km radius, which

(c) 2014. The Authors.

Published under a Creative Commons Attribution Licence. 


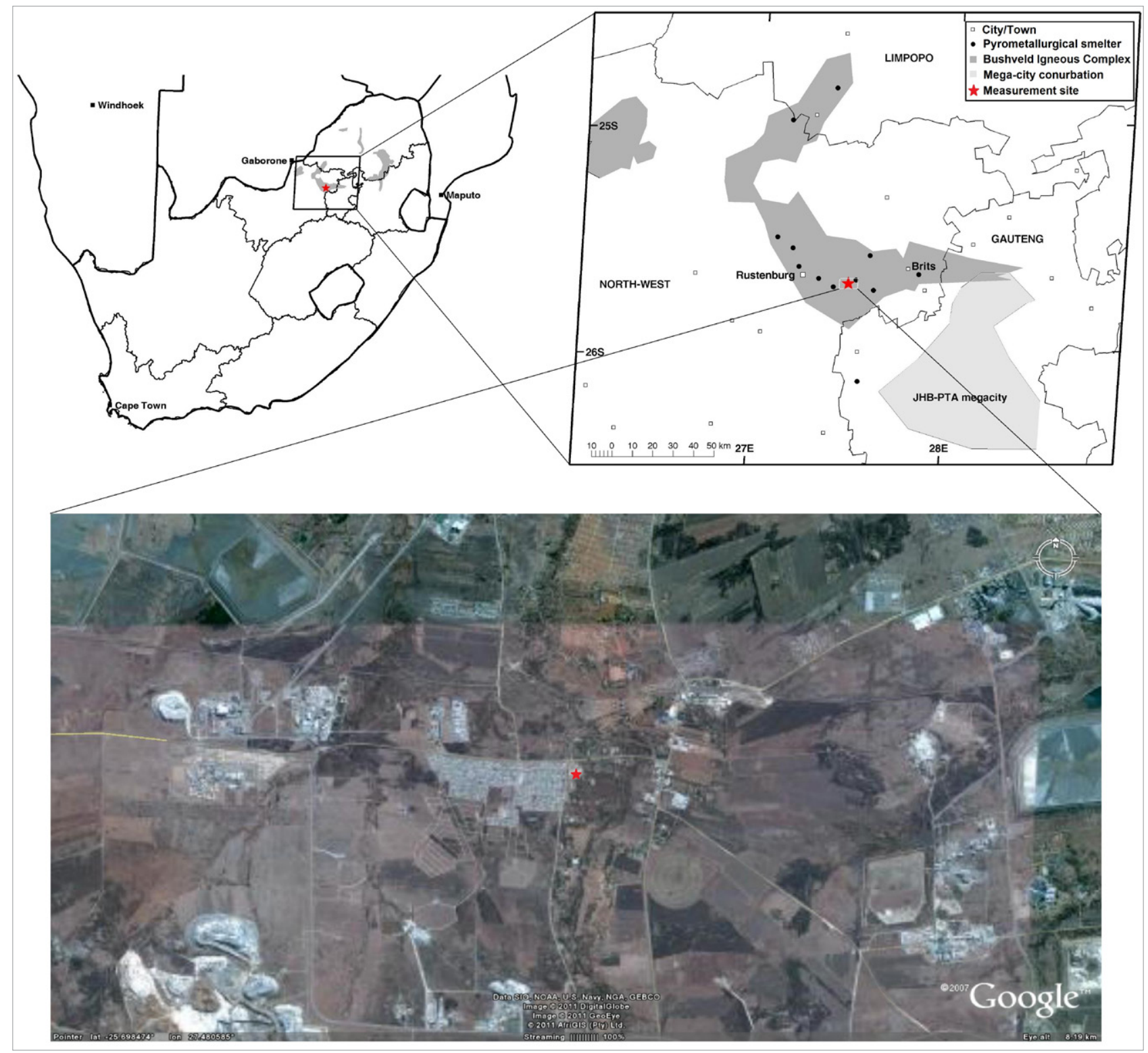

Figure 1: Geographical map of southern Africa and a satellite image indicating the location of the measurement site (25.69845 S, 27.48056 E), as well as the extent of the western Bushveld Igneous Complex and the major point sources. ${ }^{18}$ The sampling site is also shown on a satellite image obtained from Google Earth

include platinum (Pt), Cr, V, Mn and base metal production. ${ }^{18,23}$ At present, limited data exist for atmospheric trace metal concentrations in this region. ${ }^{24}$ Our general aims in this investigation were to compare trace metal concentrations to existing air quality standards, to conduct a temporal (seasonal and diurnal) and size resolved assessment of trace metal species, as well as to determine possible sources of trace metal species in the western BIC.

\section{Measurement methods and materials}

\section{Reagents}

Concentrated nitric acid $\left(\mathrm{HNO}_{3}\right.$ ) (CJ CHEM, Johannesburg, South Africa) and concentrated hydrochloric acid ( $\mathrm{HCl}$ ) (Rochelle Chemicals, Johannesburg, South Africa) were utilised for the extraction of metals from samples collected on filters. Metal standards were obtained from Sigma Aldrich (Johannesburg, South Africa) for inductively coupled plasma mass spectrometry (ICP-MS) analysis. All these reagents and standards were analytical grade (AR) chemicals and were used without further purification or processing. Deionised water (18.2 M $\Omega$ ) was used for all dilutions.

\section{Site description}

Measurements were conducted at Marikana (25.69845 S, 27.48056 $\mathrm{E}, 1170 \mathrm{~m} \mathrm{AMSL}$ ), which is a small village situated approximately $35 \mathrm{~km}$ east of Rustenburg, in the North West Province of South Africa (Figure 1). The site was situated in a residential area on the property of the Marikana municipal clinic, which provided access to electrical supply and also ensured the safe keeping of equipment. ${ }^{18}$ In Figure 1 , the location of the sampling site is also shown on a satellite image obtained from Google Earth. A detailed description of the measurement site and possible sources of pollutant species in the area are presented in Venter et al. ${ }^{18}$

A mobile monitoring station comprehensively equipped with atmospheric measurement instruments was placed at the site. Measurements included meteorological data, radiation measurements, inorganic gaseous species concentrations $\left(\mathrm{SO}_{2}, \mathrm{NO}_{x}, \mathrm{O}_{3}\right.$ and $\left.\mathrm{CO}\right)$, as well as physical and chemical properties of aerosol particles. A complete list and detailed description of the atmospheric measurement instruments in the mobile monitoring station used at Marikana have been provided previously. 18,25-27 


\section{Sampling methods}

$\mathrm{PM}_{2.5}$ and $\mathrm{PM}_{10}$ particulate matter samples were collected with MiniVol ${ }^{\mathrm{TM}}$ samplers (C\&M Consulting Engineers, Pretoria, South Africa) on 2- $\mu \mathrm{m}$ Whatman Teflon $^{\circledR}$ filters (Merck, Johannesburg, South Africa) with a $46.2 \mathrm{~mm}$ diameter. The mini-volume samplers were programmed to filter air at a sampling rate of $5 \mathrm{~L} / \mathrm{min}$ for $12 \mathrm{~h} /$ day for a period of 6 days. Each sample contained PM collected for $72 \mathrm{~h}$. The flow rate of the mini-volume samplers was verified once a month with a flow meter. The starting time for sampling was altered every 6 days in order to obtain diurnal samples. Daytime sampling commenced at 06:00, while nighttime sampling started at 18:00, corresponding to the approximate light and dark periods, respectively. Sampling was performed for 1 year from November 2008 until October 2009.

The Teflon ${ }^{\circledR}$ filters were carefully inspected prior to sampling to ensure that they were not damaged. Extra care was taken not to damage or contaminate the filters. Filters were handled with latex gloves and tweezers throughout the investigation. The filters were exchanged after each sampling period and stored in airtight Petri dishes in a freezer. Samples were removed from the freezer $24 \mathrm{~h}$ before analyses.

\section{Analysis}

A surface analysis of sampled filters was performed with an FEI Quanta 2000 scanning electron microscope (SEM) (Hillsboro, OR, USA) with an integrated Oxford Instruments INCA x-sight 400 electron dispersion spectroscope (EDS) (Scotts Valley, CA, USA) microanalysis system.

Atmospheric trace metals were extracted from the collected filters by means of hot acid extraction, as described previously. ${ }^{28}$ An ICP-MS analysis of the extracted samples was conducted with an Agilent 7500c series model (Santa Clara, CA, USA). Concentrations of the metals in ambient PM were calculated using the US Environmental Protection Agency (EPA) compendium method 10-3.5. ${ }^{29}$ The following 27 trace metal species were detected by means of ICP-MS analysis: $\mathrm{Na}, \mathrm{Mg}$, $\mathrm{Al}, \mathrm{K}, \mathrm{Ca}, \mathrm{Ti}, \mathrm{V}, \mathrm{Cr}, \mathrm{Mn}, \mathrm{Fe}, \mathrm{Co}, \mathrm{Ni}, \mathrm{Cu}, \mathrm{Zn}, \mathrm{As}, \mathrm{Cd}, \mathrm{Pt}, \mathrm{Hg}, \mathrm{Pb}$, beryllium $(\mathrm{Be})$, boron $(\mathrm{B})$, selenium $(\mathrm{Se})$, palladium $(\mathrm{Pd})$, barium $(\mathrm{Ba})$, gold $(\mathrm{Au})$, thallium $(\mathrm{TI})$, and uranium $(\mathrm{U})$. Metal concentrations that were below the detection limit of the ICP-MS were considered to have concentrations of half the detection limit of the specific metal species considered. This assumption is precautionary and is frequently made in health-related environmental studies. ${ }^{30}$

\section{Statistical analysis}

In an attempt to identify possible sources of trace metals measured in this area, principal component factor analysis (PCFA) with Varimax rotation (v. 13.0 SPSS Inc., Chicago, IL, USA) was performed on the data set. PCFA has been used widely in receptor modelling to identify major source categories affecting a given receptor site. The technique operates on sample-to-sample fluctuations of the normalised concentrations. It does not directly yield concentrations of species from various sources, but identifies a minimum number of common factors whose variance often accounts for most of the variance of species. ${ }^{4,31}$

\section{Results and discussion}

\section{Trace metal concentrations}

The annual average, 3-monthly average and 72-h concentration ranges of all the metals considered are listed in Table 1. Particulate Pd, $\mathrm{Hg}$, $\mathrm{TI}$ and $\mathrm{U}$ were below the detection limit of the analytical technique for the entire year. The concentrations of the trace metal species $\mathrm{Ca}$, $\mathrm{Co}, \mathrm{As}, \mathrm{Cd}, \mathrm{Ba}$ and $\mathrm{Au}$ were above the detection limit for only $25 \%$ or less of the time during the sampling period. Concentrations reported for these metals ( $\mathrm{Pd}, \mathrm{Hg}, \mathrm{TI}, \mathrm{U} \mathrm{Ca}, \mathrm{Co}, \mathrm{As}, \mathrm{Cd}, \mathrm{Ba}, \mathrm{Au}$ ) are therefore likely to be an overestimate because of the precautionary assumption described previously. These metals (shaded in Table 1) are therefore not discussed further as a result of the uncertainties associated with their concentrations.
Atmospheric Fe had the highest annual average concentration of 2.54 $\mu \mathrm{g} / \mathrm{m}^{3}$, with concentrations ranging between $0.42 \mu \mathrm{g} / \mathrm{m}^{3}$ and 19.01 $\mu \mathrm{g} / \mathrm{m}^{3}$. Mg was the second most abundant species in the atmosphere with an annual average concentration of $2.04 \mu \mathrm{g} / \mathrm{m}^{3}$. The atmospheric concentrations of $\mathrm{Mg}$ ranged between $0.01 \mu \mathrm{g} / \mathrm{m}^{3}$ and $13.6 \mu \mathrm{g} / \mathrm{m}^{3}$. $\mathrm{Na}, \mathrm{B}$ and $\mathrm{Al}$ also had relatively high concentrations in the atmosphere with annual average levels of $1.41 \mu \mathrm{g} / \mathrm{m}^{3}, 1.30 \mu \mathrm{g} / \mathrm{m}^{3}$ and $1.28 \mu \mathrm{g} / \mathrm{m}^{3}$, respectively. The maximum concentration recorded for B was $14.53 \mu \mathrm{g} /$ $\mathrm{m}^{3}$, while $\mathrm{Na}$ had a maximum level of $7.23 \mu \mathrm{g} / \mathrm{m}^{3}$.

In order to regionally and globally compare the trace metal concentrations determined at Marikana, trace metal levels reported in a selection of previous studies in similar environments are also listed in Table 1. Although the aerosol sampling periods and frequencies for most of these previous trace metal studies were not similar to the aerosol sampling period (1 year) and frequency (once a week) in this investigation, these results could be used to contextualise the trace metal concentrations determined at Marikana. Two of these studies were conducted in South Africa - Rustenburg ${ }^{16}$ and the Vaal Triangle ${ }^{12}$ - while the other investigations were performed in urban and industrial regions in the United Kingdom (UK) ${ }^{32}$, Portuga ${ }^{33}$ and Argentina ${ }^{34}$.

Rustenburg is a city approximately $40 \mathrm{~km}$ west of Marikana and is also situated in the western BIC. In one of the studies cited, trace metal samples were collected for a few months at two sites in the Rustenburg region in 2006. In our study, Fe was also the most abundant species with a much higher atmospheric concentration compared to the Fe levels determined at Marikana. $\mathrm{Mn}$ and $\mathrm{Cr}$ had the second and third highest atmospheric concentrations, respectively. These species were also significantly higher compared to the concentrations of these trace metals measured at Marikana.

The Vaal Triangle is a highly industrialised region approximately $170 \mathrm{~km}$ south of Marikana. In the cited study, aerosols were collected in this area at three sites during a 3-day sampling campaign in July 2006 and another 3-day sampling campaign in March 2007. Atmospheric trace metal concentrations measured at the Vaal Triangle were generally lower compared to the trace metal concentrations determined at Marikana. $\mathrm{Na}$ had the highest atmospheric concentration and was twofold higher compared to the Marikana measurements of $\mathrm{Na}$. Fe was the second most abundant species in the Vaal Triangle region.

The annual average trace metal concentrations measured in 2009 at the 24 urban and industrial atmospheric monitoring sites of the UK Heavy Metals Monitoring Network are also presented in Table 1. In this monitoring network, samples are obtained for a period of 1 week. A comparison of the atmospheric trace metal concentrations measured at Marikana with these measurements indicates that the trace metal concentrations measured at Marikana were orders of magnitude higher. Trace metal concentrations measured at an industrial region in Lisbon, Portugal in 15 24-h samples collected during November and December 2001 were also much lower. However, the average Ca concentration at this site in Portugal was significantly higher.

The atmospheric trace metal concentrations in this study were also compared to a similar study conducted in an urban and industrial site in La Plata City in Argentina in 1993. Argentina is also considered to be a developing country. Ca concentrations were considerably higher compared to Marikana, where $\mathrm{Ca}$ concentrations were below the detection limit of the instrument $25 \%$ or less of the time. Similar to Marikana, Fe and Mg were also abundant metal species in La Plata City. Atmospheric concentrations of $\mathrm{Mn}, \mathrm{Cu}, \mathrm{Zn}$ and $\mathrm{Pb}$ compared well to the atmospheric levels of these species measured at Marikana.

\section{Comparison to ambient air quality standards}

Also indicated in Table 1 are the existing ambient air quality guidelines and standard limit values for trace metal species prescribed by the WHO air quality guidelines for Europe ${ }^{11}$, the European Commission Air Quality Standards ${ }^{35}$, the National Ambient Air Quality Standards of the US EPA ${ }^{36}$ and the National Air Quality Act of the South African Department of Environmental Affairs (DEA). ${ }^{37}$ There are currently 
guidelines and standards for only seven trace metal species, of which the abovementioned institutions prescribe limit values for only some of these trace metal species. A comparison of the annual average, 3-month average and 72-h concentrations to the appropriate standard limit values indicates that only As and $\mathrm{Ni}$ exceeded an existing limit set by the European Commission of Air Quality Standards during the sampling period. The $0.26 \mu \mathrm{g} / \mathrm{m}^{3}$ annual average concentration of As and the 0.03 $\mu \mathrm{g} / \mathrm{m}^{3}$ annual average level of $\mathrm{Cd}$ exceeded their annual standard limit values of $0.006 \mu \mathrm{g} / \mathrm{m}^{3}$ and $0.005 \mu \mathrm{g} / \mathrm{m}^{3}$, respectively. These results, however, have to be considered within context, because As and Cd were detectable less than $25 \%$ of the time during the sampling period, as mentioned previously. The annual average concentration of $0.33 \mu \mathrm{g} /$ $\mathrm{m}^{3}$ measured for $\mathrm{Ni}$ (range $0.02-1.92 \mu \mathrm{g} / \mathrm{m}^{3}$ ) exceeded the set standard limit value of $0.02 \mu \mathrm{g} / \mathrm{m}^{3}$ by an order of magnitude. This finding can possibly be attributed to the metallurgical activities, especially those associated with base metal refining, in the region. This result will be explored further in subsequent sections in this paper. The WHO guideline of $2.5 \times 10^{4} \mu \mathrm{g} / \mathrm{m}^{3}$ listed for $\mathrm{Cr}$ is only for atmospheric concentrations of the $\mathrm{Cr}(\mathrm{VI})$ oxidation state with a lifetime risk of 1:1 000000 . The annual average $\mathrm{Cr}$ concentration of $0.24 \mu \mathrm{g} / \mathrm{m}^{3}$ determined is the total atmospheric $\mathrm{Cr}$ concentration, i.e. all the oxidation states of $\mathrm{Cr}$. This result can therefore not be compared to this guideline. $V$ is the only trace metal species with a 24-h standard limit value. Therefore, 72-h samples collected in this study could not be directly compared to this standard limit value. However, the $72-\mathrm{h}$ maximum value of $0.40 \mu \mathrm{g} / \mathrm{m}^{3}$ was well below the 24-h limit of $1 \mu \mathrm{g} / \mathrm{m}^{3}$.

It is important to note that $\mathrm{Pb}$, which is the only metal species that has a standard limit value prescribed by the South African DEA, did not exceed any of the standards. De-leading of petrol in South Africa could be considered to be partially responsible for these low concentrations. It is also significant to refer to the concentrations of $\mathrm{Hg}$, which were below the detection limit of the analytical instrument for the entire sampling period. This finding was expected, as particulate $\mathrm{Hg}$ only forms a small fraction of the total atmospheric $\mathrm{Hg}$, with $\mathrm{Hg}$ being mainly present in the atmosphere as gaseous elemental $\mathrm{Hg} .{ }^{38,39}$ Measurement of ambient $\mathrm{Hg}$ concentrations is receiving increasing attention in South Africa and it is likely that a standard limit value for $\mathrm{Hg}$ levels will be prescribed in the near future.

\section{Temporal variations}

\section{Seasonal trends}

Similar seasonal patterns were observed for daytime and night-time measurements. Therefore, the monthly average totals, i.e. daytime and night-time trace metal concentrations, were calculated. The monthly average total trace metal concentrations in the $\mathrm{PM}_{10}$ and $\mathrm{PM}_{2.5}$ fractions for the 12-month sampling period are shown in Figure 2.

The total trace metal concentrations in the $\mathrm{PM}_{10}$ fraction peaked from April to September, with the highest level recorded during June. This observation can at least partially be ascribed to seasonal variations in meteorological parameters. In Figure 3, the precipitation (a) and wind velocity (b) data for the entire sampling period are presented. Although not perfectly correlated, there seems to be a relationship between periods of precipitation and low total atmospheric $\mathrm{PM}_{10}$ trace metal concentrations. In the period December 2008 to mid-March 2009, frequent rain events occurred, which resulted in significant atmospheric removal of $\mathrm{PM}_{10}$ particles. This relatively wet period was followed by a dry period from the beginning of April 2009 to the middle of October 2009. Rain events again increased from October 2009 up until the end of the sampling period in November 2009.

From Figure 3 it is also evident that the lowest wind speeds were measured from the beginning of May 2009 up until the end of August 2009. This seasonal wind pattern was expected, because it is well known that more stable tropospheric conditions occur during the winter months, while more unstable conditions are associated with summer. Considering strict monovariance conditions, i.e. only wind variation, it can be expected that higher wind velocities would lead to higher $\mathrm{PM}_{10}$ trace metal concentrations, especially of dust from crustal species. ${ }^{2,4}$ However, in this study, higher wind velocities coincided with wet periods. During these periods, the soil is also wet and dust is not that easily swept from the surface of the earth by strong winds to become airborne. The presented precipitation and wind velocity data indicate that wet removal processes of atmospheric $\mathrm{PM}_{10}$ trace metals are more significant than wind generation thereof.

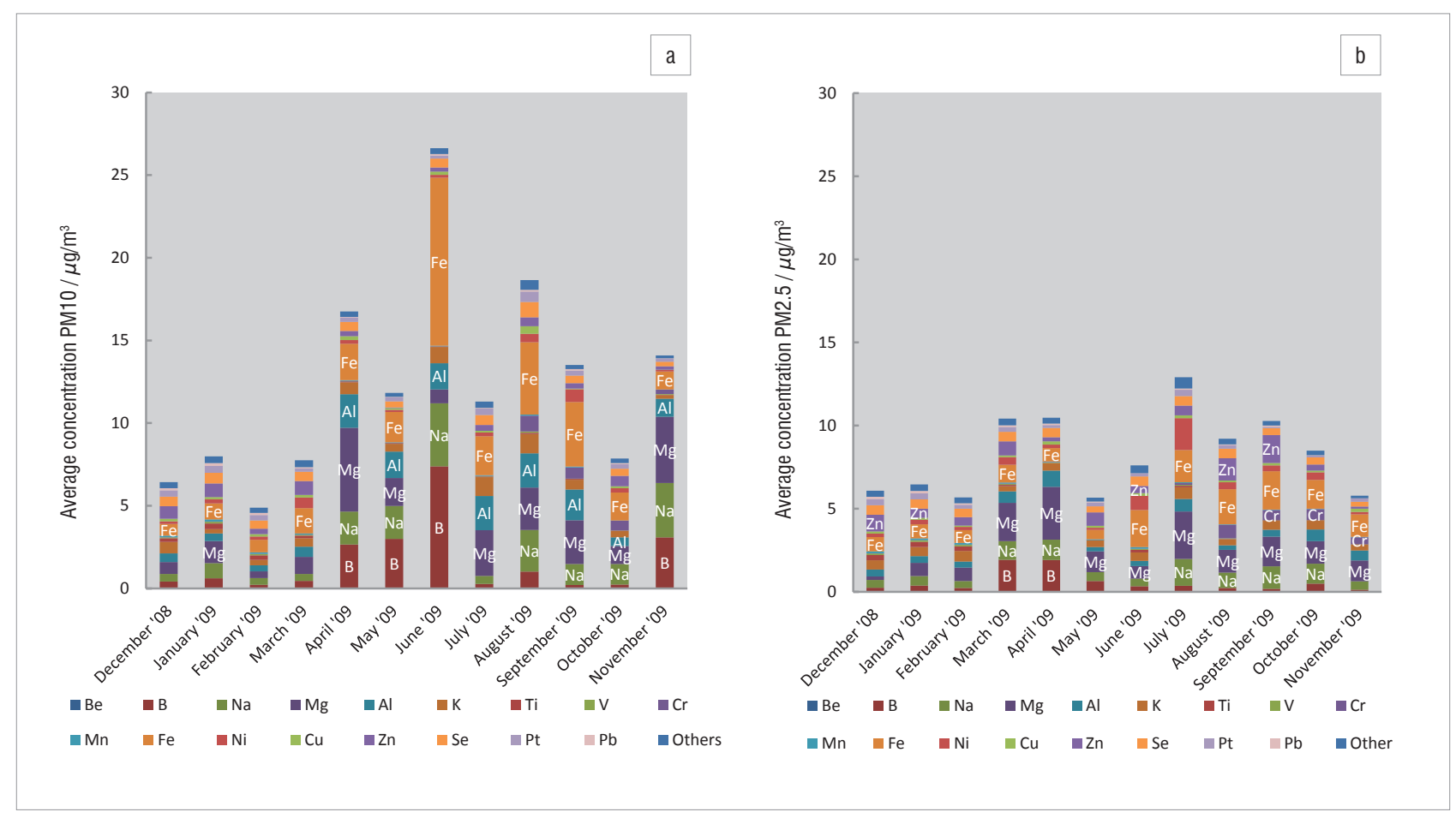

Figure 2: Monthly total trace metal concentration in the (a) $\mathrm{PM}_{10}$ and (b) $\mathrm{PM}_{2.5}$ fractions. 


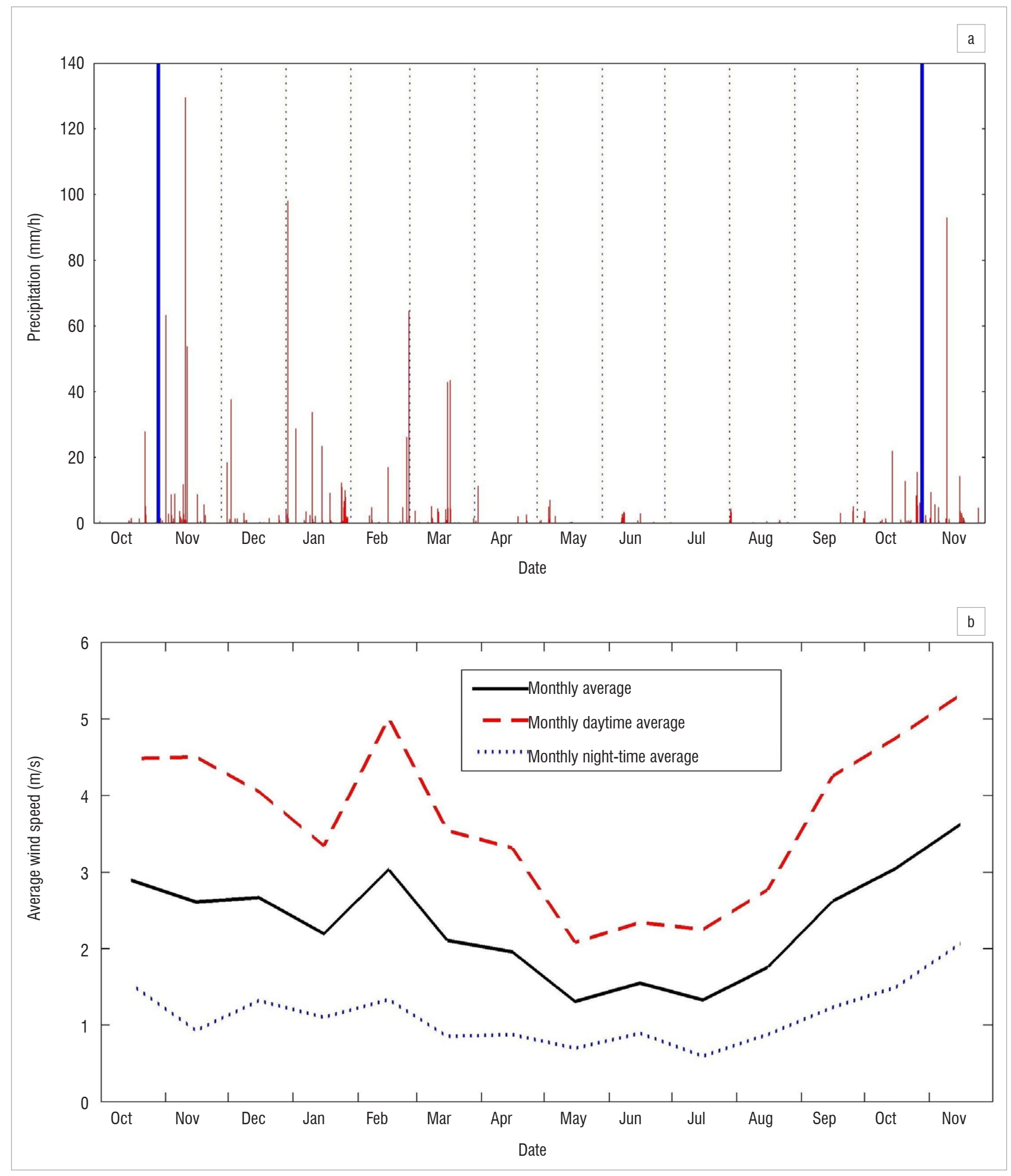

Figure 3: (a) Precipitation events and (b) monthly average wind speeds measured for the entire year of sampling.

A less significant seasonal trend is observed for the trace metal concentrations in the $\mathrm{PM}_{2.5}$ fraction (Figure 2). The highest concentrations were determined during the winter month of July. Compared to the chemical composition of atmospheric $\mathrm{PM}_{10}$, a larger fraction of $\mathrm{PM}_{25}$ usually consists of species associated with chemical processes (natural or anthropogenic). $\mathrm{PM}_{10}$ is, for instance, usually strongly associated with windblown dust of crustal species. This implies that dust suppression in the wetter months has a significant influence on $\mathrm{PM}_{10}$ concentrations in the atmosphere. Fractionally, a larger portion of the $\mathrm{PM}_{25}$ composition will originate from processes such as local biomass and domestic burning (household combustion for space heating and cooking), fossil fuel combustion, pyrometallurgical processes and secondary particle formation. Because of the nature of $\mathrm{PM}_{2.5}$ sources, smaller particle concentrations are replenished faster than larger particles after washout events. In addition, because measurements were conducted in close proximity of the source region, it is expected that the atmospheric $\mathrm{PM}_{25}$ concentrations would increase at a faster rate after rain events. Smaller particles also have a longer lifetime in the atmosphere than larger aerosols do.

In Figure 4, monthly normalised trace metal compositions with a breakdown of trace metal species are presented for $\mathrm{PM}_{10}$ and $\mathrm{PM}_{2.5}$, respectively. From 


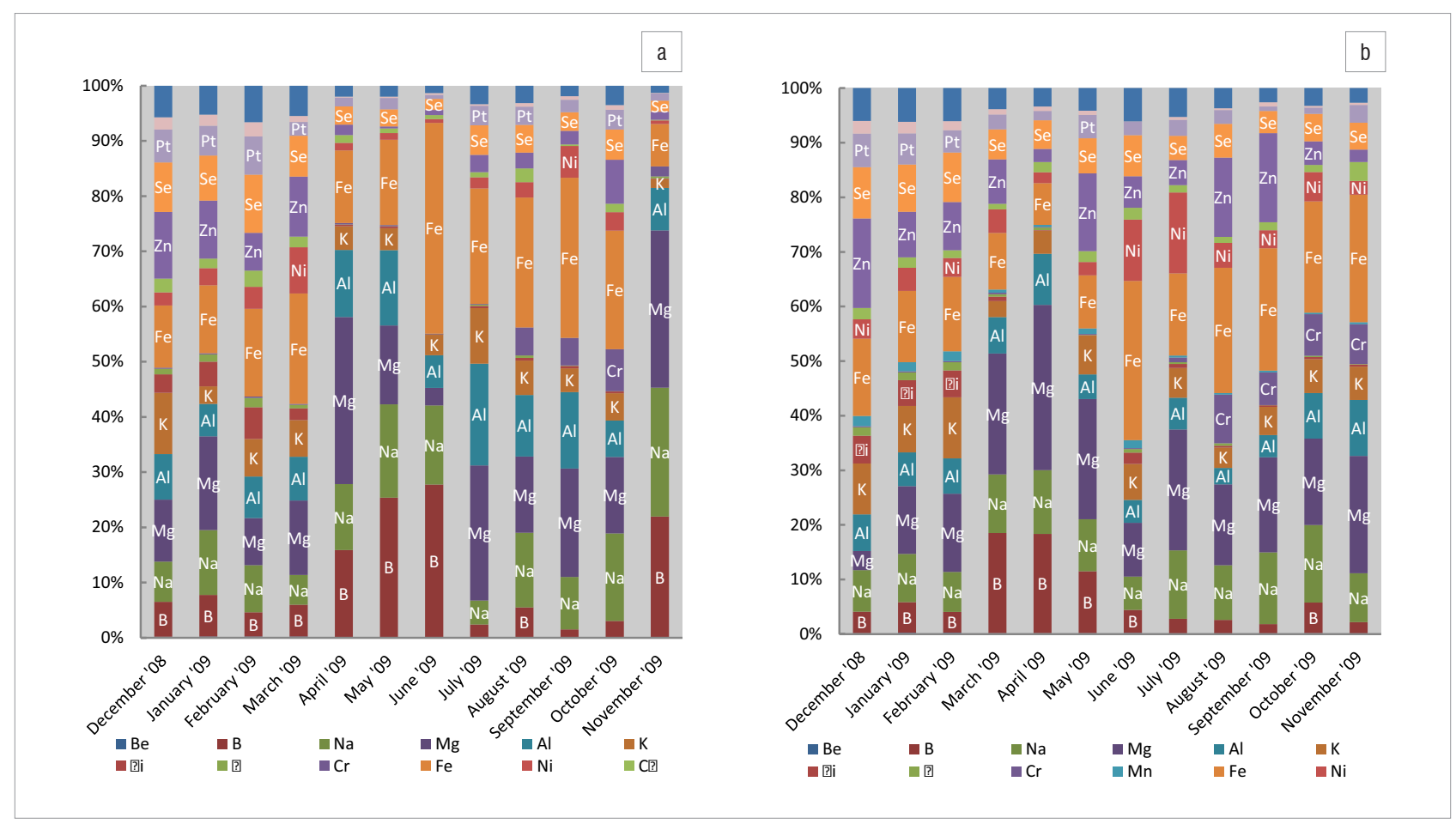

Figure 4: Normalised trace metal distribution in the (a) $\mathrm{PM}_{10}$ and (b) $\mathrm{PM}_{2.5}$ size fractions.

these figures, no obvious seasonal variations in the fractional trace metal compositions in both particle size fractions are observed. Species that were dominant in both fractions were $\mathrm{Fe}, \mathrm{Mg}, \mathrm{Al}, \mathrm{Na}$ and $\mathrm{B}$. It also seems that $\mathrm{Zn}$ and $\mathrm{Ni}$ are more prevalent in the $\mathrm{PM}_{25}$ fraction. This size resolved distribution, together with the possible sources of these species, will be discussed later.

\section{Diurnal variations}

In Figure 5, the total trace metal concentrations determined for day and night are separated into the $\mathrm{PM}_{10-25}$ and $\mathrm{PM}_{25}$ fractions. $\mathrm{PM}_{10-25}$ values were calculated by subtracting the $\mathrm{PM}_{2.5}$ total trace metal concentrations from the $\mathrm{PM}_{10}$ total trace metal concentrations. From these figures it is evident that $\mathrm{PM}_{2.5}$ is more persistent during night-time. During night-time, only $4 \%$ of the total trace metal concentrations were in the $\mathrm{PM}_{10-2.5}$ fraction, while $38 \%$ of the daytime trace metal concentration was in the $\mathrm{PM}_{10-25}$ fraction. In a study conducted at a Nordic background station, Virolahti, the trace metal concentrations of most of the species were also significantly higher in the $\mathrm{PM}_{2.5}$ fraction. ${ }^{40}$

Considering that the atmospheric $\mathrm{PM}_{10}$ load is expected to be mainly generated by crustal windblown dust, the higher daytime $\mathrm{PM}_{10-2.5}$ trace metal concentration can be explained by significant higher daytime wind speeds compared to night-time throughout the 1-year sampling period as indicated in Figure $3 \mathrm{~b}$. Increased traffic volumes during daytime could also possibly lead to higher dust emissions from roads. The higher nighttime $\mathrm{PM}_{2.5}$ trace metal concentrations can possibly be explained by the formation of low-level inversion layers trapping smaller atmospheric particles. The Highveld of South Africa is well known for its cold and dry winters, with the associated formation of strong low-level inversion layers during the night-time and early morning. These inversion layers usually dissipate in the mid-morning, resulting in the dispersal of PM. The effect (trapping of PM by the inversion layer) is expected to be stronger on smaller particles, as they are more persistent (longer lifetimes) in the atmosphere than larger particles are. Additionally, household combustion for space heating and cooking occurs more during nighttime and early mornings, especially during winter when the low-level inversion layers are still prevalent. In a study conducted at three sites in an informal settlement in South Africa, residential coal combustion accounted for $62.1 \%$ of the $\mathrm{PM}_{2.5}$ measured. ${ }^{14}$ Household combustion is usually associated with increased atmospheric $\mathrm{PM}_{2.5}$ concentrations. ${ }^{41}$

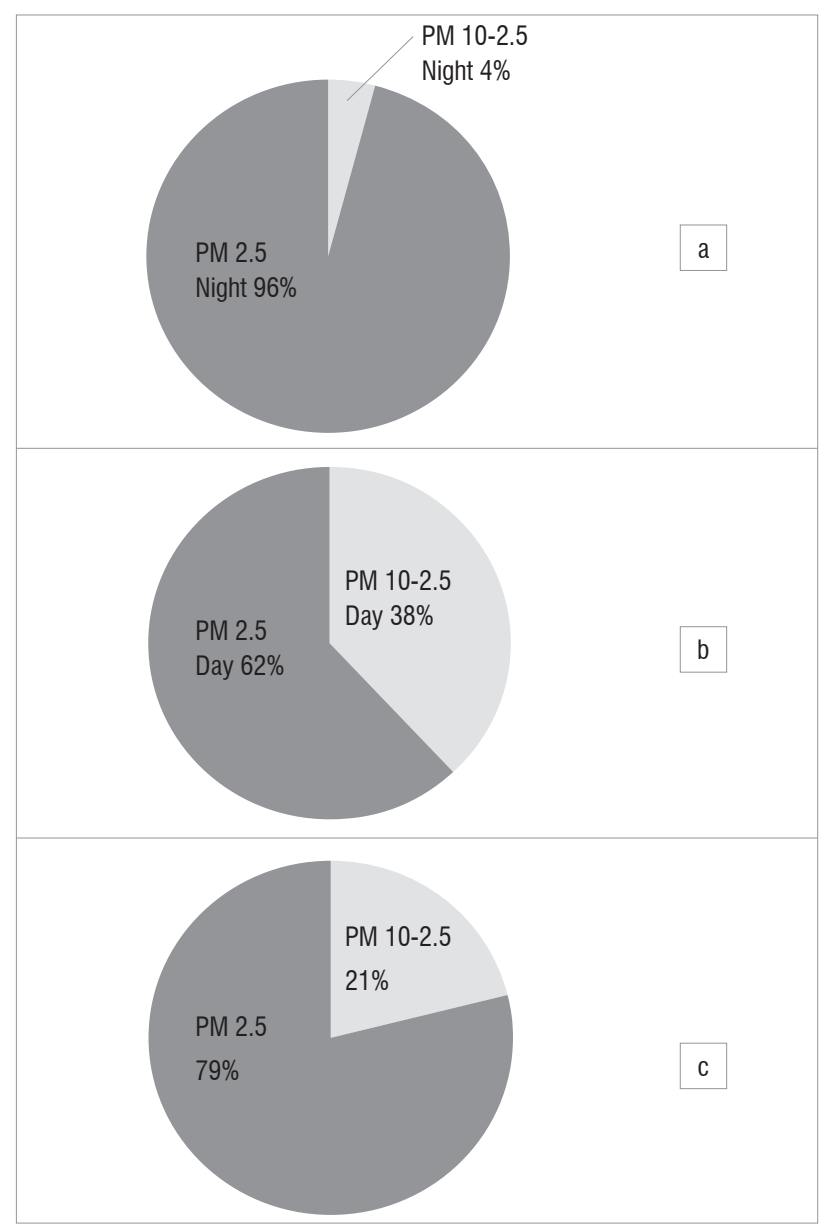

Figure 5: Total trace metal concentrations for (a) day and (b) night separated into the $\mathrm{PM}_{10-2.5}$ and $\mathrm{PM}_{2.5}$ fractions. (c) The size distribution of total (day and night) trace metal species separated into the $\mathrm{PM}_{10-2.5}$ and $\mathrm{PM}_{2.5}$ fractions. 
An air quality assessment of atmospheric measurements conducted between February 2008 and May 2010 at the Marikana sampling site indicated that household combustion was the major source of $\mathrm{PM}_{10}$ in this region. ${ }^{18}$ These authors ${ }^{18}$ also indicated that $\mathrm{PM}_{10}$ concentrations peaked in the mornings between 06:00 and 10:00, as well as in the evenings between $17: 00$ and 22:00. These peak periods could potentially have an influence on atmospheric trace metal concentrations. However, the influence of these peak concentrations on trace metal concentrations measured in this study could not be quantified, as these peaks overlapped with the daytime and night-time sampling periods during which PM was collected for trace metal measurements.

Also presented in Figure 5 are the total trace metal contributions (day and night combined) of the $\mathrm{PM}_{10-2.5}$ and $\mathrm{PM}_{2.5}$ fractions. A total $79 \%$ of the total trace metal concentrations that were determined were present in the $\mathrm{PM}_{2.5}$ fraction. This prevalence of trace metals in the $\mathrm{PM}_{2.5}$ section is indicative of the existence of significant anthropogenic sources in addition to natural processes.

\section{Size distribution of trace metals}

Each trace metal species (detected above the detection limit) was also fractionalised separately between $\mathrm{PM}_{10-2.5}$ and $\mathrm{PM}_{2.5}$. These distributions are shown in Figure 6. From these results it is evident that for all the metal species that occurred at levels above the detection limit, $40 \%$ and more of the specific metal were present in the $\mathrm{PM}_{25}$ fraction. In contrast, the $\mathrm{PM}_{10-25}$ fraction comprised only $\mathrm{Al}, \mathrm{B}, \mathrm{Fe}, \mathrm{Na}, \mathrm{K}, \mathrm{Pt}, \mathrm{Cu}, \mathrm{Mg}, \mathrm{Be}$, $\mathrm{Pb}$, Se and Ti. As mentioned previously, the $\mathrm{PM}_{10-2.5}$ fraction is usually associated with windblown dust, which is usually associated with $\mathrm{Al}$, $\mathrm{Fe}, \mathrm{Na}, \mathrm{Mg}$ and Ti. ${ }^{2-5}$ Measurements conducted at a Nordic background station in Virolahti showed significantly smaller fractions of $\mathrm{Al}$, Fe and $\mathrm{Mg}$ occurring in the $\mathrm{PM}_{25}$ size ranges compared to measurements of these species at Marikana. ${ }^{20}$ This also signifies the strong influence of industrial activities on atmospheric trace metal concentrations in the western BIC. $\mathrm{Cr}, \mathrm{Mn}, \mathrm{V}, \mathrm{Zn}$ and $\mathrm{Ni}$, which are typically associated with metallurgical activities, ${ }^{6,19-21,42}$ occurred almost exclusively in the $\mathrm{PM}_{2.5}$ fraction. The absence of these species in the coarse fraction implies the improbability of these species originating from windblown dust at this specific site. It is significant to note that pyrometallurgical smelters related directly to the production of $\mathrm{Cr}, \mathrm{V}$ and $\mathrm{Ni}$ are common anthropogenic activities in the western BIC. It is also well known that $\mathrm{Zn}$ and $\mathrm{Mn}$ are volatilised during pyrometallurgical smelting processes..$^{42}$ The percentages of these trace metals occurring in the $\mathrm{PM}_{10-2.5}$ fraction are relatively high compared to studies conducted in urban areas in Central England ${ }^{43}$, as well as in the northern and northwestern parts of Switzerland. ${ }^{44}$

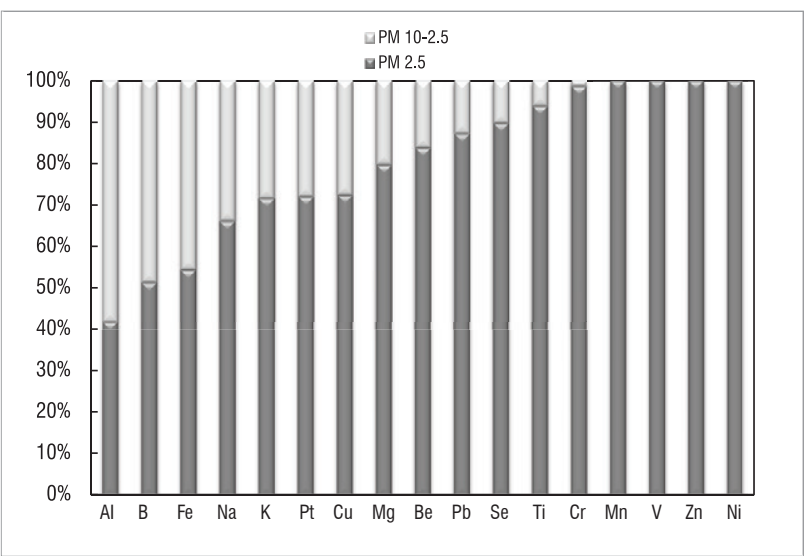

Figure 6: Size distributions of the individual metal species detected.

\section{SEM-EDS analysis}

Backscatter micrographs of a typical $\mathrm{PM}_{10}$ sampled filter are shown in Figure $7 \mathrm{a}$ and $7 \mathrm{~b}$. Particles collected are clearly visible in these micrographs. The shapes of particles can be used as an indicative method or observation to distinguish between windblown particles and particles originating from pyrometallurgical processes. Beukes at al. ${ }^{21,45}$ reported that small atmospheric rounded particles are likely to originate from the off-gas of pyrometallurgical processes. In Figure 7b, typical rounded and unevenly shaped particles are indicated with white circles and white squares, respectively. This visual observation emphasises the deductions made from chemical analyses described in previous paragraphs that particles are likely to originate from anthropogenic activities (e.g. pyrometallurgical processes), as well as from windblown dust.

In addition to visual inspection, SEM-EDS analysis was used to obtain the surface chemical composition. SEM-EDS is a semi-quantitative technique. This technique confirmed the presence of most of the trace metal species identified with ICP-MS analysis. Additionally, non-metallic species were also detected, of which $\mathrm{S}$ was the most significant. The pyrometallurgical industry associated with the large PGM industry in the western $\mathrm{BIC}$ is well known for high $\mathrm{SO}_{2}$ emissions. In general, the $\mathrm{S}$ content was more than $6 \%$ of the total elemental weight percentage, excluding $\mathrm{C}$ and $\mathrm{F}$, which are the elements associated with the Teflon filter media. This relatively high $\mathrm{S}$ content clearly indicates the strong influence of pyrometallurgical activities on the PM sampled. This finding is another confirmation of conclusions made previously with regard to the influence of anthropogenic activities on the trace metal species measured.
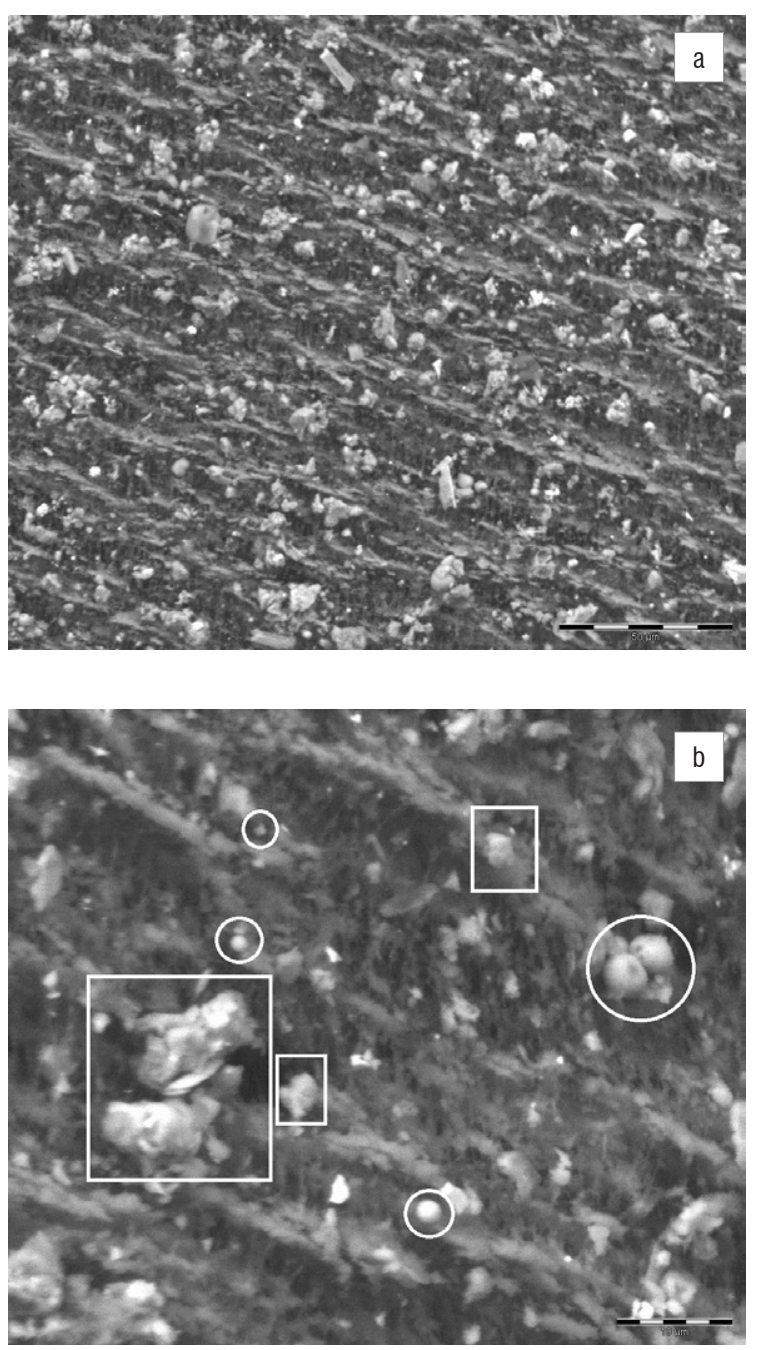

Figure 7: Backscatter micrographs of a typical $\mathrm{PM}_{10}$ filter. (a) The SEM enlargement from which electron dispersion spectroscopy analysis was performed and (b) a zoomed-in micrograph of the same surface indicating shapes of specific particulates. 


\section{Source apportionment (factor analysis)}

Principal component factor analysis was applied as an explorative tool in this investigation. Although ours is one of the most comprehensive data sets for atmospheric trace metals in South Africa, from a statistical perspective the data set was not large enough for definitive source apportionment with PCFA. Factor analysis of smaller data sets is more susceptible to statistical artefacts, such as autocorrelation or the influence of outliers. This implies that some correlations are not necessarily considerable. Therefore, only the most apparent groupings of metal species relating to expected sources in the region were identified.

The data set used for PCFA was the combined ambient concentrations determined for all 27 metal species in both the $\mathrm{PM}_{2.5}$ and $\mathrm{PM}_{10}$ fractions. The data set was subjected to Box-Cox transformation in an effort to eliminate some possible artefacts. There are no well-defined rules on the number of factors to be retained. Generally, factors that are either meaningful or with eigenvalues larger than one are kept.4,5,46 Factor loadings obtained for the data sets are presented in Figure 8. Six factors were retained from the transformed data set that explained $78.9 \%$ of the variance.

Factor 1 obtained is mostly loaded with the metal species $\mathrm{Pd}, \mathrm{Hg}, \mathrm{Tl}$, $\mathrm{U} \mathrm{Ca}, \mathrm{Co}, \mathrm{As}, \mathrm{Cd}, \mathrm{Ba}$ and $\mathrm{Au}$, which were species that were above the detection limit $25 \%$ or less of the time. Therefore, this factor was excluded in the elucidation of possible sources of trace metal species. Factor 5 obtained for this data set has high loadings of $\mathrm{B}$ and $\mathrm{Na}$, as well as moderately high loadings of $\mathrm{Al}$ and $\mathrm{Mg}$. These trace metals might be indicators of crustal sources, which are more likely to be correlated in Factor 4. Therefore, Factor 5 was considered as an unidentified source. Factor 1 and Factor 5 explained $34.5 \%$ and $6.1 \%$ of the total system variance, respectively. Four meaningful sources were identified from the factor analysis of the transformed data set and are discussed below.

Factor 2 of the modified data set was highly loaded by $\mathrm{Ti}, \mathrm{V}$ and $\mathrm{Mn}$. This factor explains $13.9 \%$ of the variance and was identified as vanadiumrelated sources. There is at least one large V smelter in the western BIC; therefore, the presence of $\mathrm{V}$ in the atmosphere in this region can be ascribed to pyrometallurgical processes. A correlation that was expected for atmospheric $\mathrm{V}$ was its association with $\mathrm{Ti}$, because titaniferous magnetite deposits are used for $\mathrm{V}$ recovery and have relatively high $\mathrm{Ti}$ content. ${ }^{47} \mathrm{Mn}$ is present in most of the ores from which metals ( $\mathrm{Cr}, \mathrm{V}$, etc.) are produced in the western BIC. Mn has a substantially lower vapour pressure than most of the heavy metals produced in this region and is therefore more volatile. ${ }^{42}$ Many of the pyrometallurgical industries will therefore be sources of atmospheric Mn. Although it is difficult to provide an exact explanation for the correlation of $\mathrm{Mn}$ with $\mathrm{V}$ and $\mathrm{Ti}$ as a result of the complexity of sources in this region, a correspondence to pyrometallurgical sources is indicated.

Factor 3 of the data set correlated to $\mathrm{Mn}, \mathrm{Fe}, \mathrm{Co}, \mathrm{Ni}$ and $\mathrm{Zn}$, which is indicative of base metals produced in this region. These base metal smelters refine base metals that were extracted during PGM processes. This factor explains $10.2 \%$ of the variances of the data. This factor was identified as the base metal industry-related sources.

Factor 4 explains $10.0 \%$ of the total system variance and was loaded with $\mathrm{Mg}, \mathrm{Al}, \mathrm{K}, \mathrm{Fe}, \mathrm{Cu}$ and Pt. Explorative investigation revealed that this factor is mainly loaded with metal species that are considered to be from windblown dust, i.e. $\mathrm{Mg}, \mathrm{Al}, \mathrm{K}$ and Fe. Therefore, this factor was identified as the crustal factor.

Another factor identified was ferrochromium-related pyrometallurgical sources. This factor was calculated in Factor 6 of the data set and has high loadings of $\mathrm{Cr}$ and $\mathrm{Fe}$. It also correlated to Ni, Pt, Na and K. Factor 6 accounts for $4.2 \%$ of the variances in the data set. A correlation between $\mathrm{Fe}$ and $\mathrm{Cr}$ was anticipated because of the presence of ferrochromium smelters in the region, as described in Venter et al. ${ }^{18}$

\section{Conclusions}

Atmospheric Fe had the highest annual average concentration, while $\mathrm{Mg}$ was the second most abundant species in the atmosphere. Relatively higher levels were also observed for $\mathrm{Na}, \mathrm{B}$ and Al. With the exception of $\mathrm{Ni}$, none of the trace metals measured at Marikana during the sampling period exceeded local and international standard limit values. The relatively high $\mathrm{Ni}$ concentration could possibly be attributed to base metal refining in the region. $\mathrm{Pb}$, which is the only metal species that has a standard prescribed by the South African DEA, did not exceed any of the standard limit values. It is also significant to mention that $\mathrm{Hg}$ was below the detection limit of the analytical instrument for the entire sampling period; a finding that was expected because particulate $\mathrm{Hg}$ only forms a small part of the total atmospheric $\mathrm{Hg}$.

The wet removal processes of atmospheric $\mathrm{PM}_{10}$ trace metals were more significant than wind generation thereof. Total trace metal concentrations

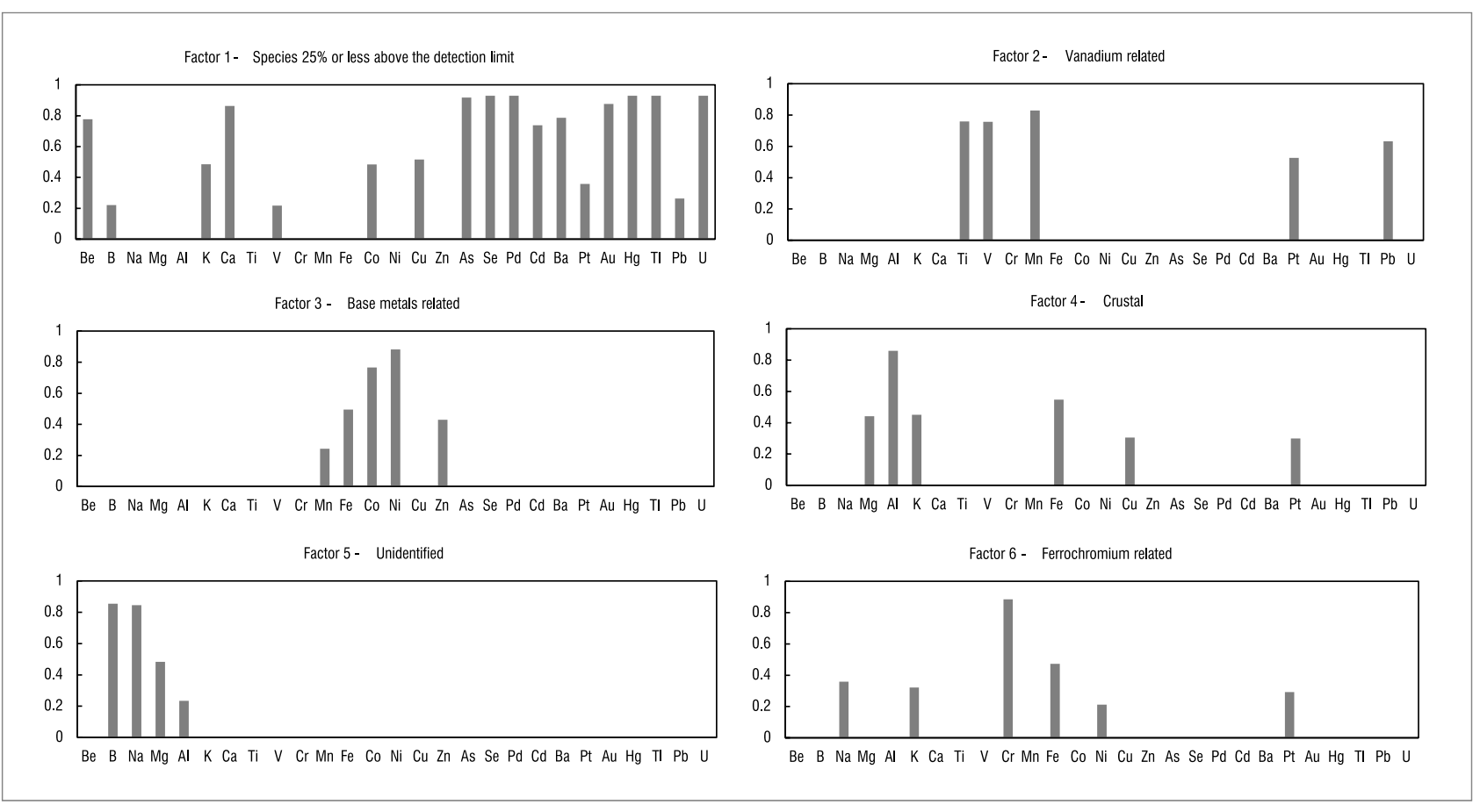

Figure 8: Principal component factor analysis with Varimax rotation of Box-Cox transformed data. 
in the $\mathrm{PM}_{10}$ fraction peaked during the dry months and were mostly washed out during the wet season. A less significant seasonal trend was observed for the trace metal concentrations in the $\mathrm{PM}_{2.5}$ fraction, which was attributed to a faster replenishment of smaller particles into the atmosphere after rain events, as well as the close proximity of the sampling site to the major $\mathrm{PM}_{25}$ sources. This finding indicates the anthropogenic origin of the smaller particles.

Separation of trace metal concentrations into $\mathrm{PM}_{10-2.5}$ and $\mathrm{PM}_{2.5}$ fractions indicated that, during night-time, only $4 \%$ of the total trace metal concentration was in the $\mathrm{PM}_{10-2.5}$ fraction, while the $\mathrm{PM}_{10-2.5}$ fraction contributed to $38 \%$ of the total daytime trace metal concentrations. An air quality assessment for atmospheric measurements conducted between February 2008 and May 2010 at the Marikana sampling site indicated that $\mathrm{PM}_{10}$ concentrations peaked in the early mornings and evenings. These peak periods could potentially have an influence on atmospheric trace metal concentrations. However, the impact of these peak periods on trace metal concentrations measured in this study could not be quantified, as the daytime and night-time sampling periods during which PM was collected for trace metal measurements overlap with these peak periods.

A total of $79 \%$ of the total trace metal levels that were measured were in the $\mathrm{PM}_{2.5}$ fraction, which indicates a strong influence of anthropogenic sources. Fractionalisation of each of the trace metal species detected showed that for each metal species, $40 \%$ and more of a specific metal was in the $\mathrm{PM}_{2.5}$ fraction, with $\mathrm{Cr}, \mathrm{V}, \mathrm{Ni}, \mathrm{Zn}$ and $\mathrm{Mn}$ occurring almost completely in the $\mathrm{PM}_{2.5}$ fraction.

Surface analysis with SEM emphasised results from chemical analysis, which indicated that a large fraction of the particles was likely to originate from anthropogenic activities and from windblown dust. SEM-EDS also detected non-metallic $S$ that is usually associated with the PGM pyrometallurgical industry, which is large in the western BIC.

Explorative factor analysis of the data set for all 27 metals detected resolved four meaningful emission sources - vanadium related, base metal related, crustal and ferrochromium related. These factors correlated very well with known pyrometallurgical sources occurring in the western BIC.

As far as we know, this paper presents the most comprehensive atmospheric trace metal concentration study conducted in South Africa published in the peer-reviewed public domain. Many trace metal studies performed in South Africa have been carried out by local authorities or certain industries and are not available in the public domain. ${ }^{24}$ Atmospheric trace metal publications available in peer-reviewed literature are limited to shorter measurement periods and reduced frequencies of sampling with fewer trace metal species identified ${ }^{12,14,16}$, or only report on specific trace metals such as $\mathrm{Pb}$ and $\mathrm{Hg}^{15,17}$.

\section{Acknowledgements}

We acknowledge the Marikana municipal clinic for providing the electricity supply and security for the mobile monitoring station. We also thank Dr Louwrens Tiedt for assistance with SEM-EDS analysis.

\section{Authors' contributions}

P.G.v.Z., J.P.B. and G.d.T. were the main investigators in this study. P.G.v.Z. and J.P.B. were the project leaders and wrote the manuscript. G.d.T. conducted this study as part of her MSc degree and performed most of the experimental work. P.G.v.Z. and J.P.B. were also study leaders of the MSc. D.M. assisted logistically in collecting the particulate matter samples at Marikana. J.H. assisted in performing the ICP-MS analysis of the collected samples. V.V., P.T., J.J.P., M.K. and L.L. made conceptual contributions.

\section{References}

1. Colbeck I. Environmental chemistry of aerosols. Oxford: Blackwell; 2008. http://dx.doi.org/10.1002/9781444305388
2. Rastogi N, Sarin MM Quantitative chemical composition and characteristics of aerosols over western India: One-year record of temporal variability. Atmos Environ. 2009;43:3481-3488. http://dx.doi.org/10.1016/j.atmosenv.2009. 04.030

3. Elefthereriadis K, Colbeck I. Coarse atmospheric aerosol: Size distributions of trace elements. Atmos Environ. 2001;35:5321-5330. http://dx.doi. org/10.1016/S1352-2310(01)00304-1

4. Al-Momani IF, Daradkeh AS, Haj-Hussein AT. Trace elements in daily collected aerosols in Al-Hashimya, central Jordan. Atmos Res. 2005;73:87-100. http://dx.doi.org/10.1016/j.atmosres.2003.09.009

5. Kulkarni P, Chellam S, Flanagan JB, Jayanty RKM. Microwave digestion—ICPMS for elemental analysis in ambient airborne fine particulate matter: Rare earth elements and validation. Anal Chim Acta. 2007;599:170-176. http:// dx.doi.org/10.1016/j.aca.2007.08.014

6. Pacyna JM, Pacyna EG. An assessment of global and regional emissions of trace metals to the atmosphere from anthropogenic sources worldwide. Environ Rev. 2001;9:269-298. http://dx.doi.org/10.1139/a01-012

7. Zheng N, Liu J, Wang Q, Liang Z. Health risk assessment of heavy metal exposure to street dust in the zinc smelting district, Northeast of China. Sci Total Environ. 2010;408:726-733. http://dx.doi.org/10.1016/j. scitotenv.2009.10.075

8. Vassilakos CH, Veros, D, Michopoulus J, Maggosa TH, O'Connor CM. Estimation of selected heavy metals and arsenic in PM10 aerosols in the ambient air of the Greater Athens Area, Greece. J Hazard Mater. 2007;140:389-398. http://dx.doi.org/10.1016/j.jhazmat.2006.11.002

9. Brown LM, Collings N, Harrison RM, Maynard AD, Maynard RL. Ultrafine particles in the atmosphere. London: Imperial College Press; 2003.

10. Karthikeyan S, Balasubramanian R, louri K. Particulate air pollution from bushfires: Human exposure and possible health effects. J Toxicol Environ Health A. 2006;69(21):1895-1908. http://dx.doi.org/10.1080/ 15287390600751264

11. Air quality guidelines for Europe. 2nd ed. World Health Organization Regional Publications, European Series No. 91. Copenhagen: World Health Organization; 2000.

12. Kleynhans EH. Spatial and temporal distribution of trace elements in aerosols in the Vaal triangle [Msc thesis]. Potchefstroom: North-West University; 2008.

13. Heal MR, Hibbs LR, Agius RM, Beverland IJ. Total and water-soluble trace metal content of urban background $\mathrm{PM}_{10}, \mathrm{PM}_{2.5}$, and black smoke in Edinburgh, UK. Atmos Environ. 2005;39(8):1417-1430. http://dx.doi. org/10.1016/j.atmosenv.2004.11.026

14. Engelbrecht JP, Swanepoel L, Chow JC, Watson JG, Egami RT. The comparison of source contributions from residential coal and low-smoke fuels, using CMB modelling in South Africa. Environ Sci Pol. 2002;5:157-167. http://dx.doi. org/10.1016/S1462-9011(02)00029-1

15. Nriagu J, Champak J, Naidoo R, Coutsoudis A. Atmospheric lead pollution in KwaZulu-Natal, South Africa. Sci Total Environ. 1996;191(1-2):69-76. http:// dx.doi.org/10.1016/0048-9697(96)05249-7

16. Kgabi NA. Monitoring the levels of toxic metals of atmospheric particulate matter in the Rustenburg district. Potchefstroom: North-West University; 2006.

17. Baker PGL, Brunke E-G, Slemr F, Crouch AM. Atmospheric mercury measurements atCape Point, South Africa. Atmos Environ. 2002;36(14):24592465. http://dx.doi.org/10.1016/S1352-2310(01)00531-3

18. Venter AD, Vakkari V, Beukes JP, Van Zyl PG, Laakso H, Mabaso D, et al. An air quality assessment in the industrialised western Bushveld Igneous Complex, South Africa. S Afr J Sci. 2012;108(9/10), Art. \#1059, 10 pages. http:// dx.doi.org/10.4102/sajs.v108i9/10.1059

19. Cramer LA, Basson J, Nelson LR. The impact of platinum production from UG2 ore on ferrochrome production in South Africa. J S Afr I Min Metall. 2004;104(9):517-527.

20. Xiao Z, Laplante AR. Characterizing and recovering the platinum group minerals - a review. Miner Eng. 2004;17:961-979. http://dx.doi.org/10.1016/j. mineng.2004.04.001

21. Beukes JP, Dawson NF, Van ZyI PG. Theoretical and practical aspects of $\mathrm{Cr}(\mathrm{VI})$ in the South African FeCr industry. J S Afr I Min Metall. 2010;110:743-750. 
22. Department of Home Affairs. Notice 495 of 2012. National Environmental Management: Air Quality Act of 2004, Declaration of the Waterberg National Priority Area, South African Government Gazette No. 35345 on 15 June 2012; Correction notice (154): Waterberg-Bojanala National Priority Area, South African Government Gazette No. 36207 on 8 March 2013.

23. Kaonga B, Kgabi NA. Atmospheric particulate matter in the Marikana mining area of Rustenburg, South Africa. Eur J Sci Res. 2009;34:271-279.

24. Piketh S, Van Nierop M, Rautenbach C. Rustenburg local municipality air quality management plan. Witbank: Palace Consulting Engineers Ltd.; 2005.

25. Laakso L, Laakso H, Aalto PP, Keronen P, Petäjä T, Nieminen T, et al. Basic characteristics of atmospheric particles, trace gases and meteorology in a relatively clean southern African savannah environment. Atmos Chem Phys. 2008;8:4823-4839. http://dx.doi.org/10.5194/acp-8-4823-2008

26. Petäjä T, Vakkari V, Pohja T, Nieminen T, Laakso H, Aalto PP, et al. Transportable aerosol characterization trailer with trace gas chemistry: Design, instruments and verification. Aerosol Air Qual Res. 2013;13:421-435.

27. Vakkari V, Laakso H, Kulmala M, Laaksonen A, Mabaso D, Molefe M, et al. New particle formation events in semi-clean South African savannah. Atmos Chem Phys. 2011;11:3333-3346. http://dx.doi.org/10.5194/acp-11-3333-2011

28. Mouli PC, Mohan SV, Balaram V, Kumar MP, Reddy SJ. A study on trace elemental composition of atmospheric aerosols at a semi-arid urban site using ICP-MS technique. Atmos Environ. 2006;40:136-146. http://dx.doi. org/10.1016/j.atmosenv.2005.09.028

29. United States Environmental Protection Agency (EPA). Compendium methods for the determination of inorganic compounds in ambient air. Compendium method 10-3.5: Determination of metals in ambient particulate matter using inductively coupled plasma / mass spectrometry (ICP/MS). Washington DC: EPA; 1999.

30. Polissar AV, Hopke PK, Paatero P, Malm WC, Sisler JF. Atmospheric aerosol over Alaska 2: Elemental composition and sources. J Geophys Res D. 1998;103(D15):19045-19057.

31. Koutrakis P, Spengler JD. Source apportionment of ambient particles in Steubenville, $\mathrm{OH}$ using specific rotation factor analysis. Atmos Environ. 1987;21(7):1511-1519. http://dx.doi.org/10.1016/0004-6981(87)90313-1

32. Brown RJC, Butterfield DM, Goddard SL, Muhunthan D, Brown AS, Beccaceci $S$, et al. Report to the Department of Environment, Food and Rural Affairs, and the Devolved Administrations, by the National Physical Laboratory: Annual Report for 2009 on the UK Heavy Metals Monitoring Network. Teddington: National Physical Laboratory; 2010.

33. Vieira BJ, Biegalski SR, Freitas MC, Landsberger S. Atmospheric trace metal characterisation in industrial area of Lisbon, Portugal. J Radioanal Nucl Chem. 2006;270(1):55-62. http://dx.doi.org/10.1007/s10967-006-0309-0
34. Bilos C, Colombo JC, Skorupka CN, Rodrigues Presa MJ. Sources, distribution and variability of airborne trace metals in La Plata City area, Argentina. Environ Pollut. 2001;111:149-158. http://dx.doi.org/10.1016/ S0269-7491(99)00328-0

35. European Commission. Air quality standards [homepage on the Internet] No date [updated 2012 Nov 30; cited 2013 Jan 24]. Available from: http:// ec.europa.eu/environment/air/quality/standards.htm.

36. United States Environmental Protection Agency. National Ambient Air Quality Standards (NAAQS) [homepage on the Internet]. No date [updated 2012 Dec 14; cited 2013 Jan 24]. Available from: http://www.epa.gov/air/criteria.html.

37. National Environmental Management Air Quality Act of 2004 section 63 Government Gazette Republic of South Africa. 2009,534:8-9. c2004 [cited 2013 Jan 24]. Available from: www.info.gov.za.

38. Lin C-J, Pehkonen S0. The chemistry of atmospheric mercury: A review. Atmos Environ. 1999;33:2067-2079. http://dx.doi.org/10.1016/S13522310(98)00387-2

39. Witt MLI, Meheran N, Mather TA, De Hoog JCM, Pyle DM. Aerosol trace metals, particle morphology and total gaseous mercury in the atmosphere of Oxford, UK. Atmos Environ. 2010;44:1524-1538. http://dx.doi.org/10.1016/j. atmosenv.2010.01.008

40. Makkonen U, Hellén $H$, Anttila P, Ferm M. Size distribution and chemica composition of airborne particles in south-eastern Finland during different seasons and wildfire episodes in 2006. Sci Total Environ. 2010;408:644-651.

41. Scorgie Y. Urban air quality management and planning in South Africa [PhD thesis]. Johannesburg: University of Johannesburg; 2012.

42. Kemink M. A holistic environmental approach to the processing of off gas wastes arising from ferro manganese alloy production [MTech thesis]. Johannesburg: Technikon Witwatersrand; 2000.

43. Allen AG, Nemitz E, Shi JP, Harrison RM, Greenwood JC. Size distribution of trace metals in atmospheric aerosols in the United Kingdom. Atmos Environ. 2001;35:4581-4591. http://dx.doi.org/10.1016/S1352-2310(01)00190-X

44. Heuglin C, Gehrig R, Baltensperger U, Gysel M, Monn C, Vonmont H. Chemical characterisation of PM2.5, PM10 and coarse particles at urban, near-city and rural sites in Switzerland. Atmos Environ. 2005;39:637-651. http://dx.doi. org/10.1016/j.atmosenv.2004.10.027

45. Beukes JP, Pienaar JJ, Lachmann G, Giesekke EW. The reduction of hexavalent chromium by sulphite in wastewater. Water SA. 1999;52:363-370.

46. Hosiokangas J, Ruuskanen J, Pekkanen J. Effects of soil dust episode and mixed fuel sources on source apportionment of $\mathrm{PM}_{10}$ particles in Kuopio, Finland. Atmos Environ. 1999;33:3821-3829. http://dx.doi.org/10.1016/ S1352-2310(98)00400-2

47. Kennedy BA. Surface mining. Baltimore, MD: Port City Press Inc.; 1990 